\section{Konsep Dasar, Proses Administrasi \\ Sarana dan Prasarana}

\section{BAB I PENDAHULUAN}

Salah satu aspek yang mendapat perhatian utama dari setiap administrator pendidikan adalah mengenai sarana dan prasarana pendidikan. Secara etimologis (bahasa) sarana berarti alat langsung untuk mencapai tujuan pendidikan. Sarana pendidikan umumnya mencakup semua peralatan dan perlengkapan yang secara langsung dipergunakan dan menunjang dalam proses pendidikan harus sesuai dengan proses pembelajarannya seperti gedung, ruang belajar atau kelas, alatalat atau media pendidikan, meja, kursi,laboratorium dan sebagainya.

Sedangkan yang dimaksud dengan prasarana adalah fasilitas yang secara tidak langsung menunjang jalannya proses pendidikan, seperti halaman yang bagus untuk melakukan pembelajaran, kebun atau taman sekolah yang enak di pandang, jalan menuju ke sekolah mudah, tata tertib sekolah, dan sebagainya.

Dengan demikian dapat di tarik suatau kesimpulan bahwa Administrasi sarana dan prasarana pendidikan itu adalah semua komponen yang secaralangsung maupun tidak langsung menunjang jalannya proses pendidikan untukmencapai tujuan dalam pendidikan itu sendiri.

Sedangkan menurut rumusan Tim Penyusun Pedoman Pembukuan Media Pendidikan Departemen Pendidikan Dan Kebudayaan, yang dimaksud dengan "sarana pendidikan adalah semua fasilitas yang diperlukan dalam proses belajar mengajar, baik yang bergerak maupun yang tidak bergerak agar pencapaian tujuan pendidikan dan berjalan dengan lancar, teratur, efektifdan efesien.Menurut keputusan menteri P dan K No 079/ 1975, sarana pendidikan terdiri dari 3 kelompok besar yaitu :

1. Bangunan dan perabot sekolah

2. Alat pelajaran yang terdiri dari pembukuan, alat-alat peraga dan laboratorium.

3. Media pendidikan yang dapat di kelompokkan menjadi audiovisual yang menggunakan alat penampil dan media yang tidak menggunaakan alat 
penampil.

Secara micro (sempit) kepala sekolah lah yang bertanggung jawab atas pengadaan sarana dan prasarana pendidikan yang di perlukan di sebuah sekolah.Sedangkan administrasi sarana dan prasarana itu sendiri mempunyai peranan yang sangat penting bagi terlaksananya proses pembelajaran di sekolaah serta menunjang tercapainya tujuan pendidikan di sebuah sekolah baik tujuan secara khusus maupun tujuan secara umum.

Terdapat pula beberapa pemahaman mengenai administrasi sarana dan prasarana di antaranya adalah :

\section{BAB II METODOLOGI PENELITIAN}

Artikel ilmiah hendaknya disusun dengan metode dan langkah-langkah yang sistematis untuk memudahkan melakukan penelitian. Pada artikel ini, peneliti menggunakan metode studi literatur dengan cara mengumpulkan literature (bahan-bahan materi) yang bersumber dari buku, jurnal, dan sumber lainnya terkait ilmu tentang Administrasi Pendidikan. Berisi abstrak yang menerangkan ringkasan dan tujuan artikel, serta keyword untuk memudahkan pembaca dalam mencari kata kunci, beserta pendahuluan latar belakang artikel dan metode penelitian artikel serta inti dari isi artikel dan kesimpulan serta daftar pustaka. Disini penulis mengambil bahan berdasarkan sumber terpecaya artikel (Hadeafriansyah 2019).

\section{BAB III KAJIAN TEORI DAN PEMBASAN}

\section{Konsep Dasar Administrasi Sarana dan Prasarana}

\section{a. Berdasarkan konsepsi lama dan modern}

Menurut konsepsi lama administrasi sarana dan prasarana itu di artikan sebagai sebuah sistem yang mengatur ketertiban peralatan yang ada di sekolah Menurut konsepsi modern administrasi sarana dan prasarana itu adalah suatu proses seleksi dalam penggunaan sarana dan prasarana yang ada di sekolah. Guru menurut konsepsi lama bertugas untuk mengatur ketertiban penggunaan sarana sekolah, menurut konsepsi modern guru bertugas sebagai administrator dan bertanggung jawab kepada kepala 
sekolah.

\section{b. Berdasarkan pandangan pendekatan} operasional tertentu

1. Seperangkat kegiatan dalam mempertahankan ketertiban penggunaan sarana dan prasarana di sekolah melalui penggunaan di siplin (pendekatan otoriter )

2. Seperangkat kegiatan untuk mempertahankan ketertiban sarana dan prasarana sekolah dengan melalui pendekatan intimidasi

3. Seperangkat kegiatan untuk memaksimalkan penggunaan sarana dan prasarana sekolah dalam proses pembelajaran (pendekatan permisif)

4. Seperangkat kegiatan untuk mengefektifkan penggunaan sarana dan prasarana sekolah sesuai dengan program pembelajaran (pendekatan intruksional)

5. Seperangkat kegiatan untuk mengembangkan sarana dan prasarana sekolah

6. Seperangkat kegiatan untuk mempertahankan keutuhan dan keamanan dari sarana dan prasarana yang ada di sekolah.

Fasilitas atau benda-benda pendidikan dapat ditinjau dari fungsi, jenis dan sifatnya.

a. Ditinjau dari fungsinya terhadap proses belajar mengajar.

Sarana pendidikan yang berfungsi langsung dalam proses pembelajaran, seperti alat pelajaran, alat peraga, dan media pembelajaran. Prasarana pendidikan berfungsi tidak langsung, seperti gedung, tanaman, halaman.

b. Ditinjau dari jenisnya yaitu:Fasilitas fisik,

Yakni segala sesuatu yang berwujud benda mati yang mempunyai peran untukmemudahkan dan melancarkan suatu usaha, seperti kendaraan, computer, mesintulis, dansebagainya.Fasilitas non fisik, segala sesuatu yang bersifat mempermudah suatu kegiatan, seperti manusia, jasa, uang.

c. Ditinjau dari sifat barangnyaa.

Barang tak bergerak dikelompokkan me 
njadi barang habis pakaiseperti kapur tulis, tinta, kertas, penghapus dan sebagainya. Barang tak habis pakai, seperti computer, mesin tulis, kendaraan dan sebagainya.

2. Proses Administrasi Sarana dan Prasarana

a) Perencanaan

Administrasi

\section{Sarana dan Prasarana}

Perencanaan sarana dan prasarana pendidikan merupakan suatu proses analisis dan penetapan kebutuhan yang diperlukan dalam proses pembelajaran sehingga muncullah istilah kebutuhan yang diperlukan (primer) dan kebutuhan yang menunjang. Dalam proses perencanaan ini harus dilakukan dengan cermat dan teliti baik berkaitan dengan karakteristik sarana dan prasarana yang dibutuhkan, jumlahnya, jenisnya dan kendalanya (manfaat yang didapatkan), beserta harganya.Berkaitan dengan ini Jones (1969) menjelaskan bahwa perencanaan pengadaan perlengkapan pendidikan di sekolah harus diawali dengan analisis jenis pengalaman pendidikan yang diprogaramkan di sekolah. Menurut Sukarna (1987) adalah sebagai berikut: a) Menampung semua usulan pengadaan perlengkapan sekolah yang diajukan oleh setiap unit kerja dan mengiventarisasi kekurangan perlengkapan sekolah.

b) Menyusun rencana kebutuhan perlengkapan sekolah untuk periode tertentu, misalnya untuk satu semester atau satu tahun ajaran.

c) Memadukan rencana kebutuhan yang telah disusun dengan perlengkapan yang tersedia sebelumya.

d) Memadukan rencana kebutuhan dengan dana atau anggaran sekolah yang tersedia. Dalam hal ini, jika dana yang tersedia tidak mencukupi untuk pengadaan semua kebutuhan yang diperlukan, maka perlu diadakan seleksi terhadap semua kebutuhan perlengkapan yang telah direncanakan dengan melihat urgensi setiap perlengkapan yang diperlukan. Semua perlengkapan yang urgen didaftar dan didahulukan pengadaannya.

e) Memadukan rencana (daftar) kebutuhan perlengkapan yang urgen dengan dana atau anggaran yang tersedia, maka perlu diadakan seleksi 
lagi dengan melihat skala prioritas.

Proses manajemen sarana prasarana pendidikan yang akan dibahas di sini berkaitan eratdengan:

\section{b) Perencanaan sarana prasarana pendidikan islam}

Perencanaan merupakan fungsi
pertama yang harus dilakukan dalam
proses manajemen. Perencanaan
sarana dan prasarana pendidikan
merupakan suatu proses analisis dan
penetapan kebutuhan yang diperlukan
dalam proses pembelajaran dan
kebutuhan yang dapat menunjang keberhasilan proses pembelajaran. Dalam proses perencanaan ini harus dilakukan dengan cermat dan teliti baik berkaitan dengan karakteristik sarana dan prasarana yang dibutuhkan, jumlahnya, jenis dan kendalanya (manfaat yang didapatkan), beserta harganya. Berkaitan dengan perencanaan ini, Jones (1969) menjelaskan bahwa perencanaan pengadaan perlengkapan pendidikan di sekolah harus diawali dengan analisis jenis pengalaman pendidikan yang di programkan sekolah.

\section{c) Pengadaan sarana dan prasarana pendidikan Islam}

Pengadaan sarana prasarana pendidikan disekolah pada hakikatnya adalah kelanjutan dari program perencanaan yang telah disusun oleh sekolah sebelumnya. Dalam pengadaan ini harus dilakukan sesuai dengan rencana yang telah disusun sebelumnya dengan memperhatikan skala prioritas yang dibutuhkan oleh sekolah dalam menunjang keberhasilan pelaksanaan proses pembelajaran.

\section{d) Inventarisasi sarana dan prasarana pendidikan Islam}

Inventarisasi dapat diartikan sebagai pencatatan dan penyusunan daftar barang-barang milik Negara secara sistematis, tertib dan teratur berdasarkan ketentuanketentuan atau pedoman-pedoman yang berlaku. Hal ini sesuai dengan keputusan mentri keuangan RI Nomor Kep.225/MK/V/4/1971 bahwa barang milik negara berupa semua barang yang berasal atau dibeli dengan dana yang bersumber baik secara keseluruhan atau bagian sebagainya dari APBN atupun dan lainya yang barang- 
barangnya

dibawah penguasaan

kantor departemen

dan

kebudayaan, baik yang berada didalam maupun luar negeri.

e) Pendistribusian Prasarana Sekolah

Penditribusian perlengkapan merupakan kegiatan pemindahan barang dan tanggung jawab penyimpanan kepada unit-unit atau orang-orang yang membutuhkan barang itu. Dalam prosesnya ada 3 hal yang harus di perhatikan yaitu ketepatan barang yang di sampaikan, baik jumlah maupun jenisnya; ketepatan sasaran penyampaiannya, ketepatan kondisi barang yang di salurkan. Ada 3 langkah yang dilakukan oleh bagian penanggung jawab penyimpanan atau penyaluran, yaitu :

1) Penyusunan alokasi barang;

2) Pengiriman barang;

3) Penyerahan barang.

Barang yang telah di terima di investarisasikan oleh panitia pengadaan, setelah kebenaranmya di periksa berdasarkan daftar yang ada perlu surat pengantar, tidak berarti semua personil sekolah bisa menggunakan secara bebas. Barang-barang tersebut perlu di atur lebih lanjut untuk memudahkan pengawasan dan pertanggung jawaban. Apabila pendistribusiannya tidak di atur dengan sebaik, pengelolaan perlengkapan sekolah akan mengalami kesulitan dalam membuat laporan pertanggung jawabannya.

\section{f) Pengadaan Administrasi Sarana dan Prasarana}

Pengadaan adalah semua kegiatan penyediaan sarana dan prasarana untuk menunjang pelaksanaan tugas. Karena fungsi dan kegiatan setiap organisasi berbeda, maka pengadaan sarana dan prasarana kantor juga tidak selalu sama antara organisasi yang satu dengan organisasi yang lain. Dalam mengadakan sarana dan prasarana tersebut harus dilakukan perencanaan terlebih dahulu.

\section{g) Inventaris Administrasi Sarana dan Prasarana}

Pengadaan semua sarana dan prasarana kantor memerlukan biaya tinggi, termasuk semua kegiatan yang 
berkaitan dengan pengelolaannya. Untuk itu diperlukan kegiatan inventarisasi. Inventarisasi sarana dan prasarana kantor adalah semua kegiatan dan usaha untuk memperoleh data yang diperlukan mengenai sarana dan prasarana yang dimiliki. Secara singkat inventarisasi dapat diartikan sebagai pencatatan terhadap sarana dan prasarana.

\section{h) Penyaluran Administrasi Sarana dan Prasarana}

Penyaluran merupakan kegiatan yang menyangkut pemindahan barang dan tanggung jawab dari instansi / pemegang yang satu kepada instansi / pemegang yang lain. Kegiatan penyaluran barang meliputi tiga bagian yaitu :

\section{1) Penyusunan Alokasi}

Untuk menghindari pemborosan dalam pembagian/ pendistribusian barang sehingga merata dan seimbang dengan kebutuhan pemakainya masing-masing, maka perlu disusun alokasi kuantitas dan frekuensi pendistribusiannya, sehingga sungguh-sungguh dapat menunjang kegiatan instruksiona

\section{2) Pengiriman Barang}

Pengiriman barang dari pusat-pusat penyalur barang perlu memperhatikan beberapa hal sebagai berikut: cara pengiriman, pengemasan, pemuatan, pengangkutan dan pembongkarang.

\section{3) Penyerahan Barang}

Dalam penyerahan barang hendaklah tidak dilupakan untuk mengisi daftar penyerahan barang, surat pengantar, faktur, tanda terima peyerahan barang, biaya pengiriman dan sebagainya.

\section{4) Pemanfaatan dan pemeliharaan}

Pemeliharaan adalah kegiatan terusmenerus untuk mengusahakan agar barang/bahan kantor tetap dalam keadaan baik atau siap untuk dipakai.

2. Pemeliharaan berdasarkan jenis barang

a. Pemeliharaan barang bergerak

Pemeliharaan barang bergerak dapat dilakukan setiap hari maupun secara berkala. Contoh: kendaraan bermotor, mesin kantor, dan alat elektronik.

b. Pemeliharaan barang tidak bergerak 
Pemeliharaan barang tidak bergerak juga dapat dilakukan setiap hari atau secara berkala untuk mengetahui sampai sejauh mana kualitas barang tersebut masih dapat digunakan. Contoh: membersihkan debu-debu yang menempel pada alat,sebaiknya dilakukan setiap hari agar alat dapat selalu terjaga kebersihannya, juga untuk mencegah kerusakan. Instalasi listrik dan air dapat dilakukan secara berkala.

\section{i) Pengawasan Administrasi Sarana dan Prasarana}

Pengawasan seluruh kegiatan Administrasi Sarana dan Prasarana Pendidikan tidak bisa berjalan sendiri tanpa dikendalikan dan diawasi, artinya setiap kegitan masing-masing akan dimonitoring setiap saat oleh pimpinan organisasi serta diperhatikan kerja samanya satu sama lain. Pengawasan bukan merupakan suau pengaturan yang kaku dan akan membatasi ruang gerak masing-masing fungsi pengelolaan, tetapi merupakan koordinasi serta akselerasi bagi seluruh fungsi pengelolaan administrasi, sehingga pemborosan waktu, tenaga dan biaya dapat dihindarkan

\section{Peran Guru dalam Administrasi Sarana Prasarana}

Kebijakan pemerintah tentang pengelolaan sarana dan prasarana sekolah tertuang di dalam UU No. 20 tahun 2003 tentang Sisdiknas pasal 45 ayat (1) yaitu "setiap satuan pendidikan formal dan nonformal menyediakan sarana dan prasarana yang memenuhi keperluan pendidikan sesuai dengan pertumbuhan dan perkembangan potensi fisik, kecerdasan intelektual, sosial, emosional dan kejiwaan peserta didik." (Mohammad Syaifuddin, 2007 : 2.36).

Adapun peran guru dalam administrasi sarana prasarana sekolah:

1. Terlibat dalam perencanan pengadaan alat bantu pengajaran.

2.Terlibat dalam pemanfaatan dan pemeliharaan alat bantu pengajaran yang digunakan guru.

3. Pengawasan dalam penggunaan alat praktek oleh siswa

\section{BAB IV KESIMPULAN}

Administrasi sarana dan prasarana 
pendidikan itu adalah semua komponen yang secaralangsung maupun tidak langsung menunjang jalannya proses pendidikan untukmencapai tujuan dalam pendidikan itu sendiri.

\section{DAFTAR PUSTAKA}

Afriansyah, H. (2019). Konsep Dasar,

Proses Administrasi Sarana dan

Prasarana. Padang. 